\title{
ArcGIS studies and field relationships of Paleoproterozoic mafic dyke swarms from the south of Devarakonda area, Eastern Dharwar Craton, southern India: Implications for their relative ages
}

\author{
Amiya K Samal ${ }^{1, *}$, Rajesh K SRivastava ${ }^{1}$ and Lokesh K Sinha ${ }^{2}$ \\ ${ }^{1}$ Centre of Advanced Study in Geology, Banaras Hindu University, Varanasi 221 005, India. \\ ${ }^{2}$ Defence Terrain Research Laboratory, Defence Research and Development Organization, \\ Metcalfe House, Delhi 110 007, India. \\ *Corresponding author.e-mail: amiyasamal007@gmail.com
}

\begin{abstract}
Google Earth Image and cross-cutting field relationships of distinct Paleoproterozoic mafic dykes from south of Devarakonda area in the Eastern Dharwar Craton has been studied to establish relative emplacement ages. The Devarakonda, covering an area of $\sim 700 \mathrm{~km}^{2}$, shows spectacular cross-cutting field relationships between different generations of mafic dykes, and is therefore selected for the present study. Although some recent radiometric age data are available for distinct Paleoproterozoic mafic dykes from the Eastern Dharwar Craton, there is no analogous age data available for the study area. Therefore, relative age relationships of distinct mafic dykes have been established for the study area using cross-cutting field relationships and GIS techniques, which shows slightly different picture than other parts of the Eastern Dharwar Craton. It is suggested that NE-SW trending mafic dykes are youngest in age (probably belong to $\sim 1.89$ Ga dyke swarm), whereas NNW-SSE trending mafic dykes have oldest emplacement age. Further, the NNW-SSE mafic dykes are older to the other two identified mafic dyke swarms, i.e., WNW-ESE $(\sim 2.18 \mathrm{Ga})$ and N-S trending $(\sim 2.21 \mathrm{Ga})$ mafic dyke swarms, as dykes of these two swarms cross-cut a NNW-SSE dyke. It provides an evidence for existence of a new set of mafic dykes that is older to the $\sim 2.21 \mathrm{Ga}$ and probably younger to the $\sim 2.37 \mathrm{Ga}$ swarm. Present study also supports existence of two mafic dyke swarms having similar trend (ENE-WSW to NE-SW) but emplaced in two different ages (one is $\sim 2.37 \mathrm{Ga}$ and other $\sim 1.89 \mathrm{Ga}$ ).
\end{abstract}

\section{Introduction}

Systematic study of mafic dyke swarms act as a tool to understand Precambrian terrains and their relative ages help to identify large igneous provinces (LIPs) of that period (Coffin and Eldholm 2005; Bryan and Ernst 2008; Ernst and Srivastava 2008; Srivastava et al. 2010, 2014a, b, c). Ultimately, this could be used to compare different crustal blocks and reconstruct their connections in past continents and supercontinents (e.g., Ernst and Buchan 1997, 2001; Bleeker 2003, 2004; Bleeker and Ernst 2006; Ernst and Bleeker 2010). Different Precambrian terrains of the Indian shield also comprise distinct Paleoproterozoic mafic dyke swarms (Murty et al. 1987; Ernst and Srivastava 2008; Srivastava et al. 2008; Chalapathi Rao and Srivastava 2012). It is

Keywords. Paleoproterozoic mafic dykes; relative age; Google Earth Image; ArcGIS; Devarakonda; Eastern Dharwar Craton. 
particularly conspicuous in the Eastern Dharwar Craton, which has been studied systematically by a number of researchers for its detailed geochemistry and petrogenesis (Murthy 1995; Halls et al. 2007; Radhakrishana et al. 2007; French and Heaman 2010; Kumar et al. 2012a, b; Srivastava et al. 2014a, $\mathrm{b}, \mathrm{c}$ and references therein; see figure 1). However, a limited radiometric age data are available for these distinct mafic dyke swarms (Halls et al. 2007; French and Heaman 2010; Srivastava et al. 2011, 2014b; Kumar et al. 2012a, b).

In general, it is believed that dykes with similar trends possibly have analogous emplacement ages, however, there are exceptions that suggest different emplacement ages for mafic dykes with similar trends (e.g., Srivastava 2006a, b; Srivastava and

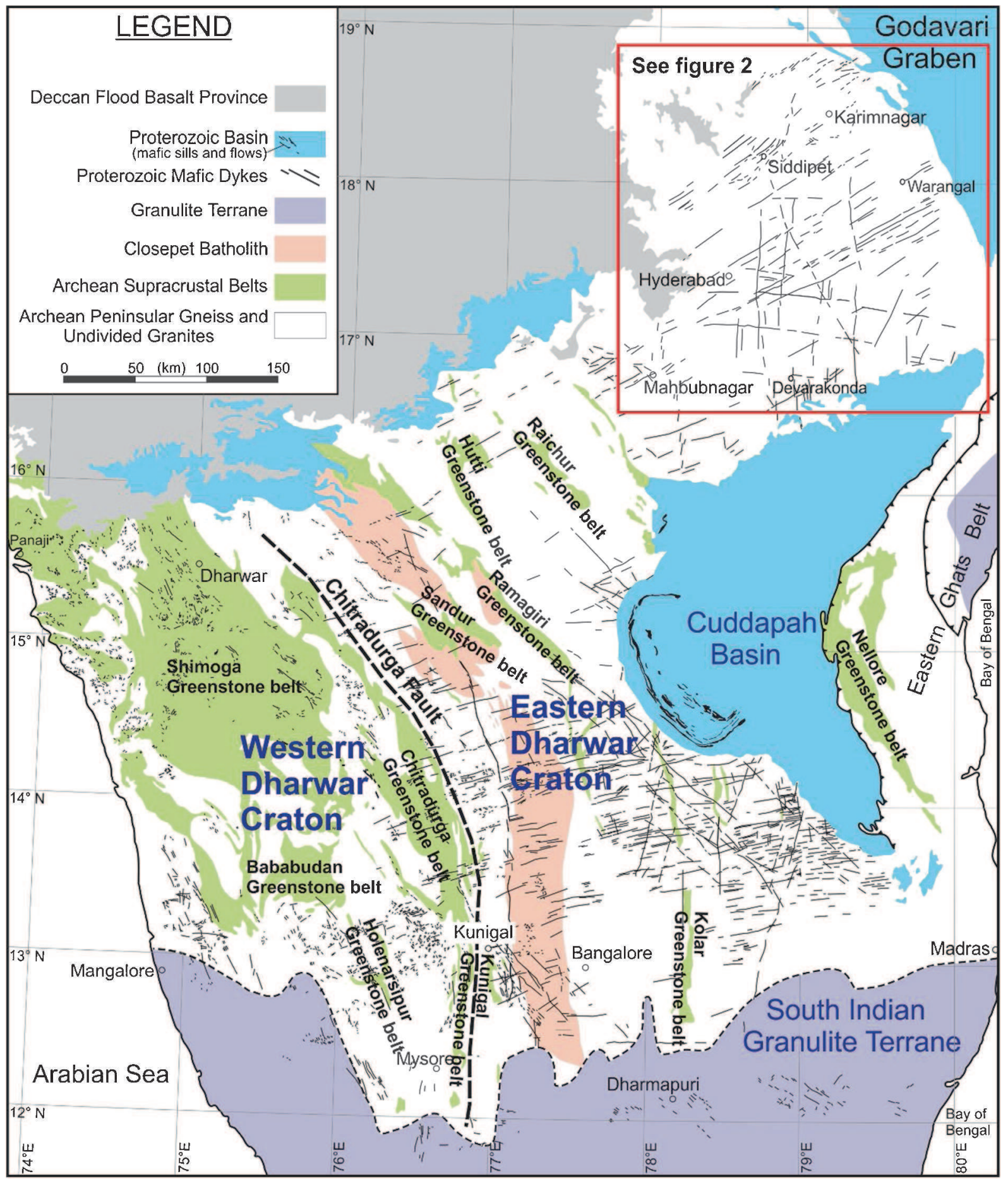

Figure 1. Simplified geological map of the Dharwar Craton showing the principal distribution of Paleoproterozoic mafic dykes (modified after French and Heaman 2010; Srivastava et al. 2014c). Detailed mafic dyke map of the studied region, the red box marked on map, is presented in figure 2 . 
Gautam 2008, 2009; Srivastava et al. 2014a). It is customary that radiometric ages obtained for a couple of dykes of a particular swarm are assigned to all the dykes of that swarm. However, it fails in many cases; many times mafic dykes having similar trends and compositions may have been emplaced in different ages. The present work is an attempt to understand this issue on the basis of crosscutting field relationships between different Paleoproterozoic mafic dykes from Devarakonda area of the Eastern Dharwar Craton (see figures 2 and 3). ArcGIS technique is also used during these exercises. Although, dyke maps for many regions of the Indian shield are available (Halls 1982; Murthy 1987; Ramachandra et al. 1995; French et al. 2008), however, most of them are based on satellite Landsat imageries and, therefore, missing many important features; for example, either many dykes are not traced or dykes are marked but actually do not exist. Therefore, perhaps this is the first genuine attempt to introduce mafic dyke map using ArcGIS technique for any region of India. It would also be constructive to understand relative emplacement ages of different generations of mafic dyke swarms of the study area.

\section{Geological setting}

Indian shield comprises of seven Archaean cratons, amongst which Dharwar Craton has been studied, in detail, by several researchers (Naqvi and Rogers1987; Ramakrishnan and Vaidyanadhan 2010 and references therein). Based on lithological and metamorphic patterns, ages of crustal provinces and crustal thickness, the Dharwar Craton is further divided into

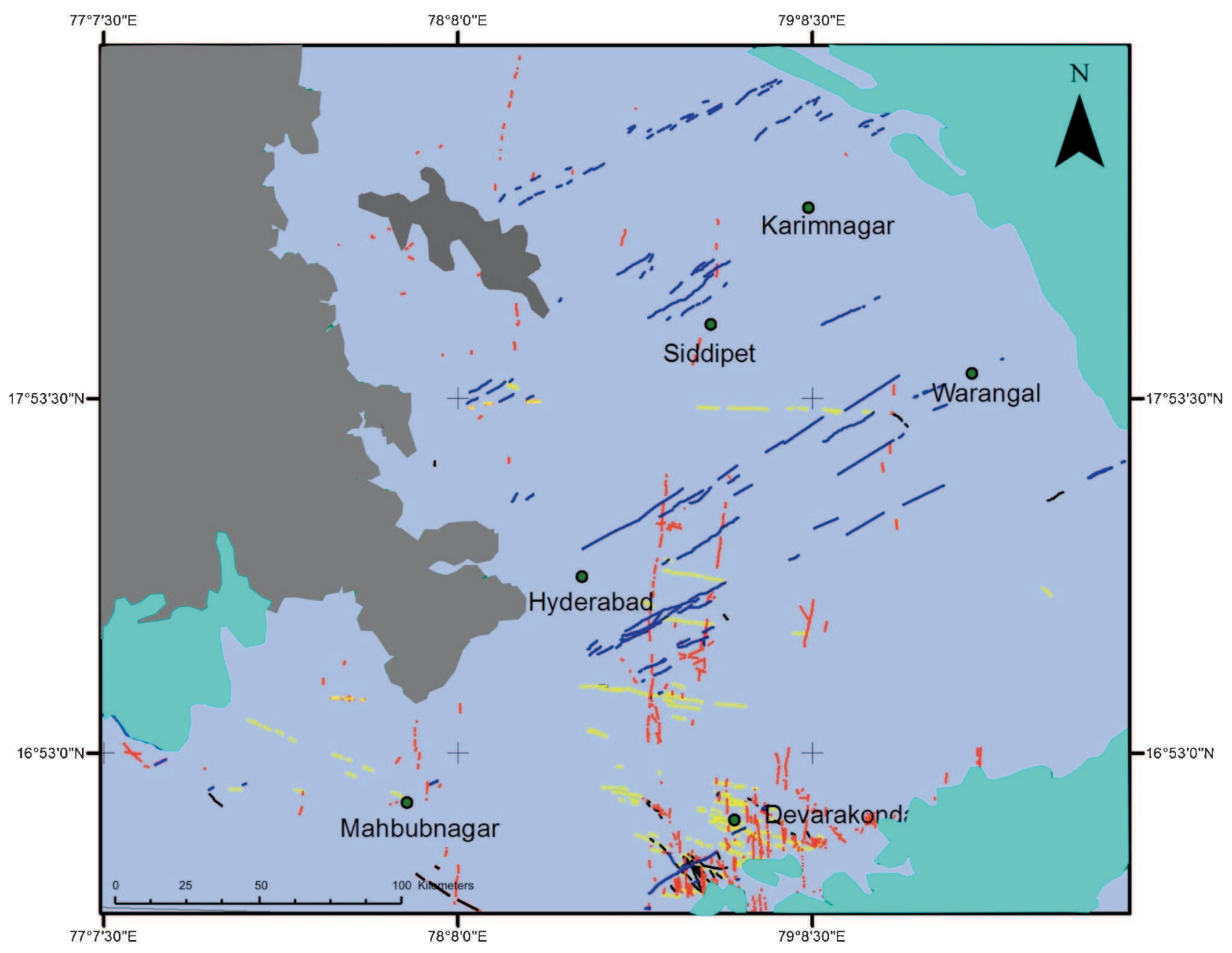

DeccanFlood Basalt

Proterozoic Basin

Archean Peninsular Gneisss and Undivided Granites

Figure 2. Map showing Paleoproterozoic mafic dykes of northern parts of the Eastern Dharwar Craton based on published dyke maps (e.g., Halls 1982; Murthy 1987; Radhakrishana et al. 2007, 2013; French et al. 2008; French and Heaman 2010), field data, Google Earth Image and ArcGIS. Blue colour: NE-SW; Yellow: WNW-ESE; Red: N-S; Black: NW-SE. 


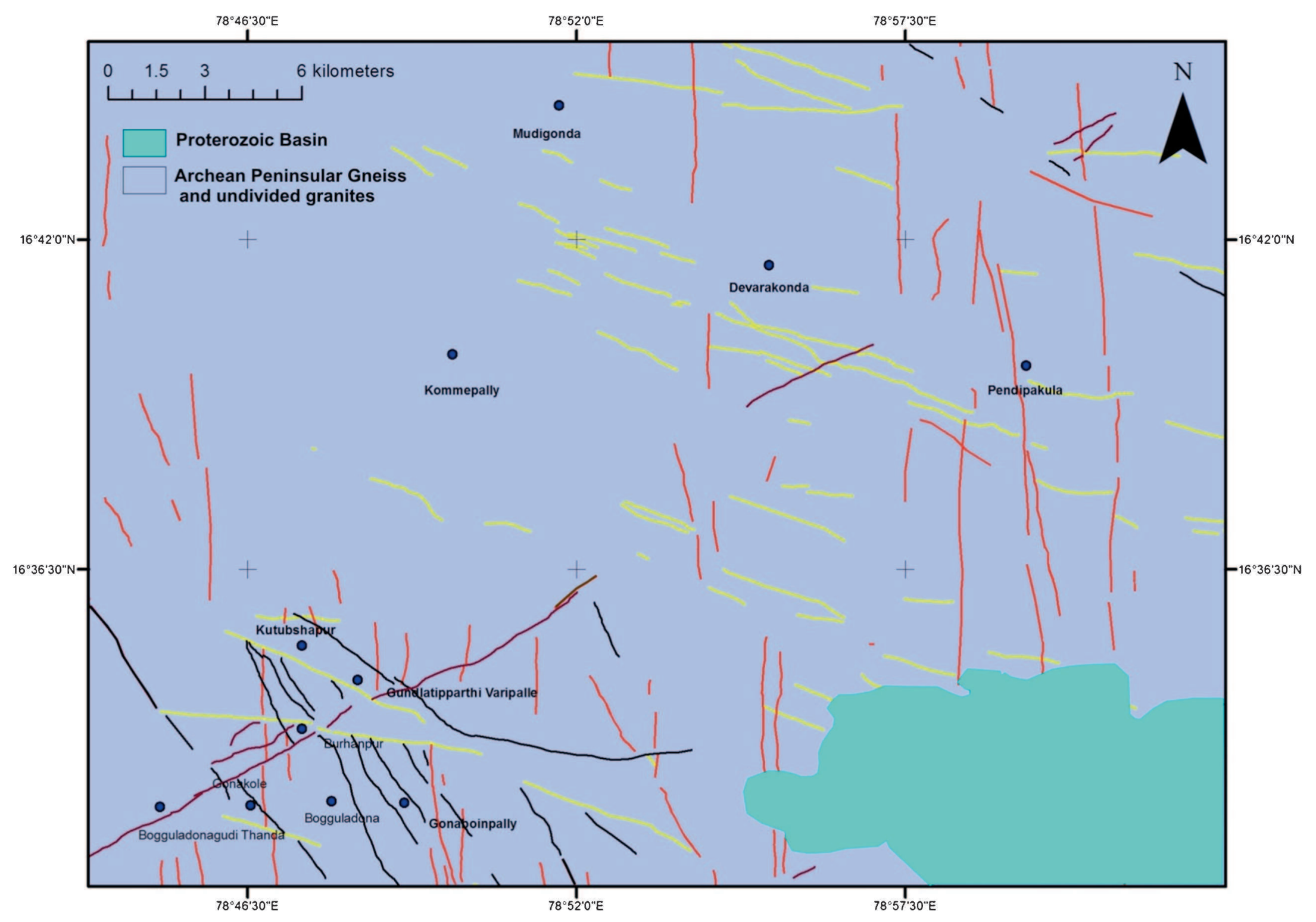

Figure 3. Map showing Paleoproterozoic mafic dykes of the Devarakonda region, Eastern Dharwar Craton based on published dyke maps (e.g., French et al. 2008; French and Heaman 2010; Radhakrishna et al. 2013), field data, Google Earth Image and ArcGIS. Purple colour: NE-SW; Yellow: WNW-ESE; Red: N-S; Black: NW-SE. 
eastern and western cratons (Jayananda et al. 2006, 2013a, b; Chardon et al. 2008; Mahadevan 2008). This division is geologically well visible as a prominent wide mylonitic shear zone represented by the Chitradurga fault (see figure 1; Mahadevan 2008). The detailed geology of the Dharwar Craton is available elsewhere in the literature (Chardon et al. 2008, 2011; Ramakrishnan and Vaidyanadhan 2010; Jayananda et al. 2013a, b and references therein).

Paleoproterozoic mafic dykes of different compositions, ages and trends are well exposed all over the Dharwar Craton, however, they are more spectacular in the Eastern Dharwar Craton (Halls et al. 2007; Radhakrishana et al. 2007; French and Heaman 2010; Srivastava et al. 2014a, b, c and references therein; see figures 2 and 3). Mafic dykes exposed in south of the Devarakonda region (covering an area of $\sim 700 \mathrm{~km}^{2}$ ) in the northern part of the Eastern Dharwar Craton (see figure 3) are of special interest for the present study as they represent four different trends and show spectacular cross-cut field relationships with each other. These Paleoproterozoic mafic dykes intrude Archaean supracrustals, Archaean and Proterozoic granitoids. They vary in length from few meters to tens of kilometres, whereas width varies between 1 and $400 \mathrm{~m}$. With the help of available $\mathrm{U}-\mathrm{Pb}$ radiometric age data on the mafic dykes of the Eastern Dharwar Craton at least three discrete Paleoproterozoic large igneous provinces (LIPs) have been identified, which include $\sim 2.37$ Ga Bangalore LIP [consisting of mostly ENE-WSW to NE-SW trending Bangalore dyke swarm (Halls et al. 2007; French and Heaman 2010; Kumar et al. 2012a)], $\sim 2.21$ to $\sim 2.18$ Ga Pan-Dharwar LIP [consisting of NW-SE to WNW-ESE trending $\sim 2.18 \mathrm{Ga}$ Mahbubnagar swarm (French and Heaman 2010) and N-S to NNW-SSE trending $\sim 2.21$ Ga Kunigal swarm (Srivastava et al. 2011, 2014c)] and E-W to ENE-WSW trending dyke swarm associated with 1.89 Ga Bastar-Dharwar LIP (French et al. 2008; Srivastava et al. 2014a).

\section{Methods}

The Google Earth Image provides free usage of satellite imagery of entire Earth's surface with high spatial resolution, which can be used as a potential tool for regional land use/cover mapping. It has been successfully used for regions with high heterogeneous landscapes (e.g., Almeer 2012; Hu et al. 2013). For the present study, the Google Earth Images (6.0.3.2197) captured between March 2, 2012 and June 1, 2014 were used.

A Geographic Information System (GIS) is used for the manipulation and management of digital spatial (geographic) and related attribute data for mapping (Huisman and By Rolf 2001). ArcGIS is a geographic information system (GIS) for working with maps and geographic information over a wide range of applications (Legg 1994; Rajesh 2004). For the present study, an ArcGIS advanced version 10.0 (ArcInfo) was used for the preparation of dyke map. Mafic dykes of different generations and their trends of the selected area are digitized manually with the help of Google Earth Image for the preparation of mafic dyke map. Mafic dykes can easily be delineated from surrounding Archaean/Proterozoic granitoids, i.e., country rocks by their contrasting colours, tones and textures. Granitoids are significantly light coloured as compared to mafic dykes, which show deep brown to black colour. In general, dykes appeared as long serrated ridges, such as linearly arranged hills. Such data was saved as 'KML' file which is later converted into 'layer' file with the help of ArcGIS software for preparation of final map.

Detailed field studies were carried out to substantiate and cross-check the data garnered through the Google Earth Image and the ArcGIS. Cross-cutting field relationships between different generations of mafic dykes and country rocks together with radiometric ages have been used as such studies could be the best elements to interpret their relative ages. At some places, a slight displacement is noticed, which is thought to be due to later intrusion of mafic dykes. No radiometric age data is available for mafic dykes of the study area except a couple of Paleomagnetic ages (Radhakrishna et al. 2013). The selected area contains four major mafic dyke swarms of different trends and show cross-cutting relationships. Based on different trends and available radiometric age data for the mafic dykes of similar trends (exposed in other parts of the Eastern Dharwar Craton), these four dyke swarms are recognized as D1 (NE-SW), D2 (WNW-ESE), D3 (N-S), and D4 (NNW-SSE). Field data are collected from different locations that include Gonaboinapally, Gonakole, Bogguladona, Gondlatipparthi Varipalle, Bogguladonagudi Thanda, Kutubshapur, Burhanpur, etc. At most of these places, mafic dykes of different trends offset each other with a prominent displacement (see figure 5). Figure 4 shows field photographs of cross-cutting relationships between D1 and D3 near the village Gundlatipparthi Varipalle.

\section{Discussion}

Cross-cutting field relationships, Google Earth Image, and available radiometric ages altogether provide an excellent tool in preparing a mafic dyke map of an area, which ultimately helps to construct relative ages of the dykes emplaced in 
that region. Using such techniques together with ArcGIS analyses, a mafic dyke map for northern parts of the Eastern Dharwar Craton (figure 2) and comprehensive similar map for the Devarakonda area (figure 3) were prepared. Most of the published geological maps showing distribution of mafic dykes of the selected area were also taken into consideration (Halls 1982; Murthy 1987; Radhakrishana et al. 2007, 2013; French et al. 2008; French and Heaman 2010 and references therein).

\subsection{Relationships between D3 and D4 (Location 1; figure 5)}

West to the village Kutubshapur, a N-S D3 mafic dyke cross-cuts NW-SE D4 mafic dyke, which suggests that D4 is older than D3. Available $\mathrm{U}-\mathrm{Pb}$ age for the $\mathrm{N}-\mathrm{S}$ mafic dykes are $\sim 2.21-$ $2.22 \mathrm{Ga}$ (Srivastava et al. 2011, 2014b). Therefore, age of NNW-SSE mafic dyke is older than $\sim 2.21 \mathrm{Ga}$.

\subsection{Relationships between D1, D2 and $D_{4}$ (Location 2; figure 5)}

Near the village Burhanpur, mafic dykes show complex cross-cutting relationship between WNW-ESE D2, and NNW-SSE D4. At this point, D2 cross-cuts $\mathrm{D} 4$, which indicates that D4 is older than D2. Available U-Pb age for the WNW-ESE mafic dykes are $\sim 2.18 \mathrm{Ga}$ (French and Heaman 2010; Srivastava et al. 2011, 2014b). These remarkable field observations and available $\mathrm{U}-\mathrm{Pb}$ ages for $\mathrm{D} 2$, and $\mathrm{D} 3$ sets of mafic dykes (Halls et al. 2007; French and Heaman 2010; Srivastava et al. 2011, 2014a) clearly suggest emplacement of D4 mafic dyke prior to the $\sim 2.21-2.22 \mathrm{Ga}$. It is difficult to interpret any cross-cutting relationship between D1 and D2 due to complex field relationship with D4. A similar picture is also observed at south of the village Gonakole (Location 4).

\subsection{Relationships between D1 and D3 (Locations 3 and 5; figure 5)}

At many places, N-S trending mafic dyke (D3) is clearly offset by NE-SW mafic dyke. It is well observed near the village Gondlatipparthi Varipalle (Location 3) and north of the village Gonakole (Location 5). A displacement is noticed in D3, which probably happened during emplacement of D1 magmatic phase. From this cross-cutting relationship one can easily conclude that D3 is older than D1.

It is important to mention that the D1 dykes [densely distributed all across the Eastern Dharwar Craton (see figure 1)] are thought to be an integral part of the $\sim 2.37$ Ga Bangalore Dyke swarm (Halls et al. 2007; Radhakrishana et al. 2007; French and Heaman 2010; Kumar et al. 2012a b). However, recently Srivastava et al. (2014a) have suggested that some of the NE-SW trending mafic dykes belong to younger phase of mafic magmatism, particularly $\sim 1.89$ Ga. This assumption is based on contrasting geochemical characteristics observed from ENE-WSW to NE-SW trending mafic dykes which clearly suggests existence of two magmatic events; one at $\sim 2.37 \mathrm{Ga}$ and other at $\sim 1.89 \mathrm{Ga}$ (Srivastava et al. 2014a). On the other hand, D3 dyke phase is a part of N-S trending $\sim 2.21-2.22 \mathrm{Ga}$ Kunigal mafic dyke swarm (Ernst and Srivastava 2008; French and Heaman 2010; Srivastava et al. 2011, 2014b and references therein).
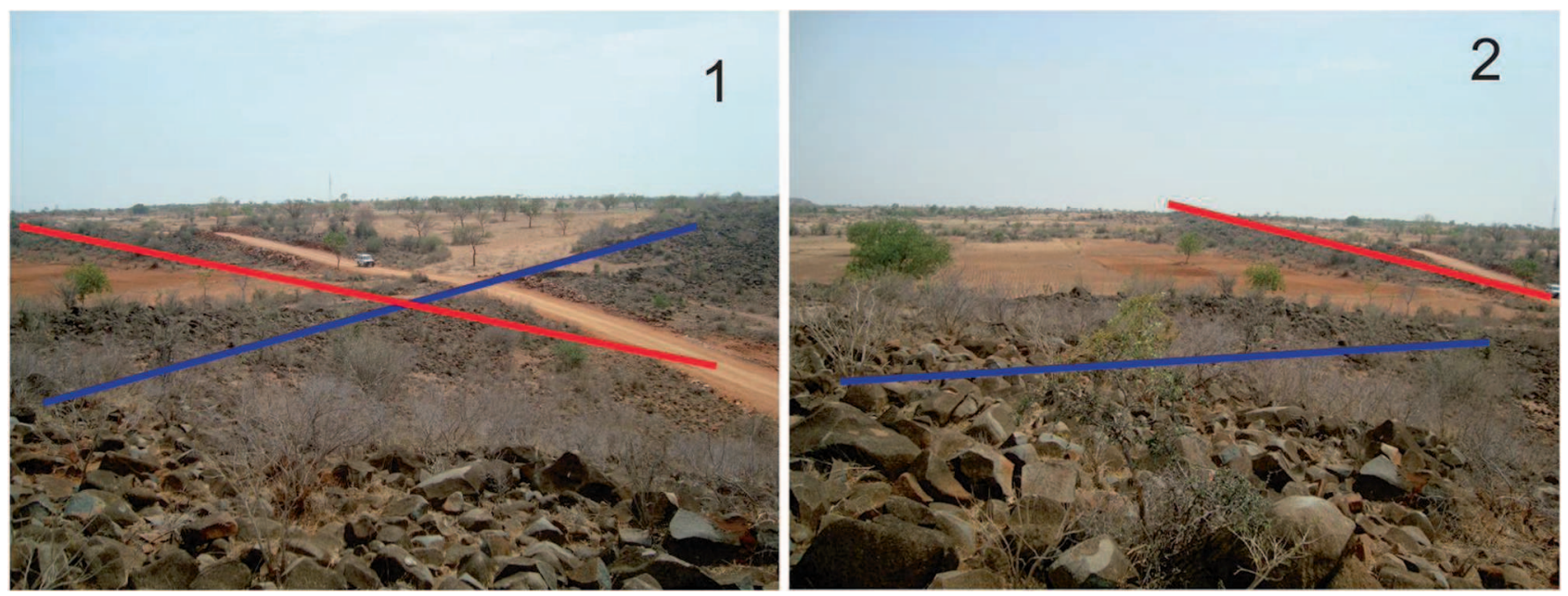

Figure 4. Field photographs showing cross-cut field relationships between D1 and D3 mafic dykes near the village Gundlatipparthi Varipalle (see Location 3; figure 5). In both photographs, a N-S mafic dyke (D3; red in colour) cuts NE-SW trending mafic dyke (D1; blue in colour). 


\subsection{Relationship between D2 and D3 (Location 4; figure 5)}

In the south of the village Gonakole (Location 4), a N-S D3 mafic dyke is offset by WNW-ESE D2 mafic dyke. This clearly suggests that D3 mafic dyke is older than D2 mafic dyke. D3 mafic dykes are a part of $\sim 2.21-2.22$ Ga Kunigal mafic dyke swarm, whereas D2 mafic dykes are a part of $\sim 2.18$ Ga Mahbubnagar dyke swarm (e.g., French and Heaman 2010; Srivastava et al. 2011, 2014b). Observed cross-cutting relationships between D2 and D3 corroborates available geochronological age data, which signifies two closely spaced yet distinct periods of short-lived dyke emplacement (French and Heaman 2010).

From these field settings of D2, D3 and D4, available geochronological age data and geochemical characteristics, it is concluded that all the NE-SW trending mafic dykes are not co-genetic and are fed from two different magmas at different ages; one at $\sim 2.37 \mathrm{Ga}$ and the other at $\sim 1.89 \mathrm{Ga}$. This conclusion is well supported by their distinct geochemical characteristics; older mafic dykes $(\sim 2.37 \mathrm{Ga})$ are
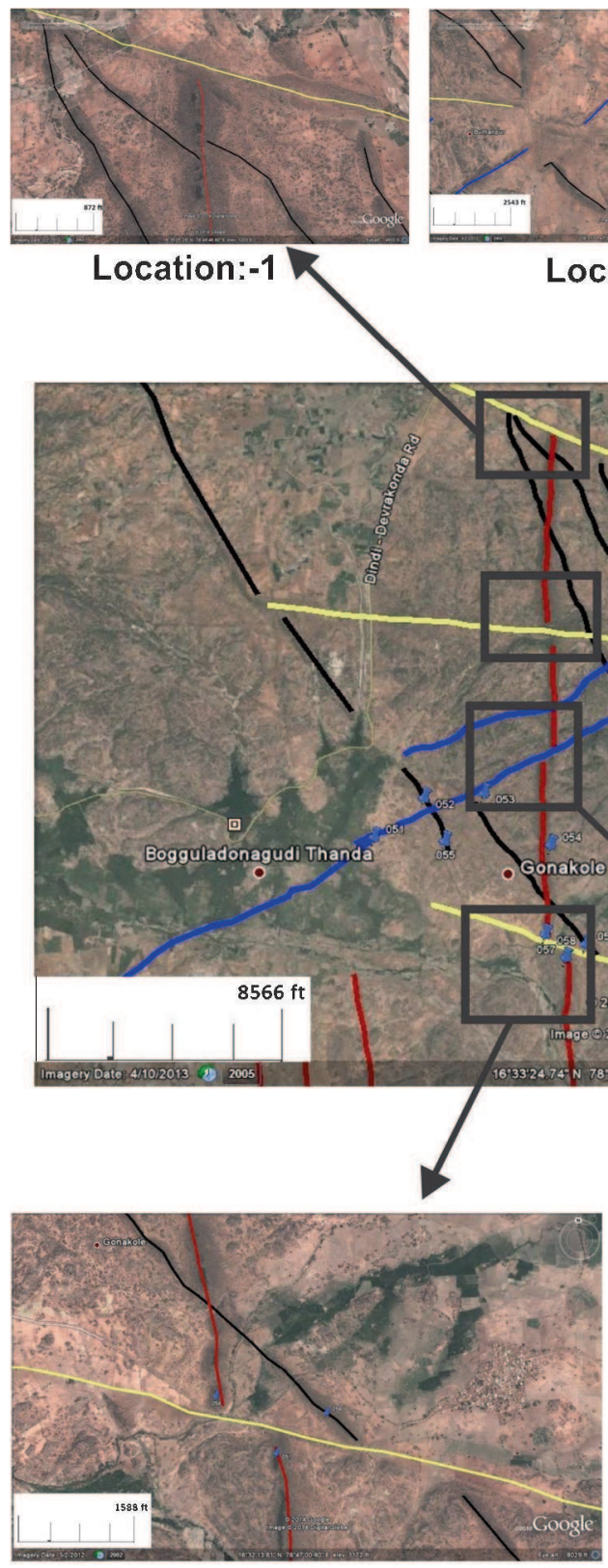

Location:-4

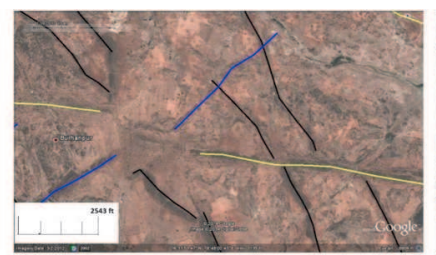

Location:-2

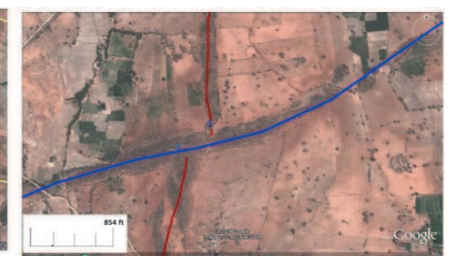

Location:-3 4 
derived from a depleted mantle source, whereas the younger set of mafic dykes $(\sim 1.89 \mathrm{Ga})$ shows its derivation from a comparatively enriched mantle source (cf. Piipsa et al. 2011; Srivastava et al. 2014a). Further, N-S trending mafic dyke (D3) is older than NE-SW trending mafic dyke (D1) that perhaps belongs to $\sim 1.89$ Ga swarm; assigning $\sim 2.37 \mathrm{Ga}$ age to this NE-SW mafic dyke is not justified. Based on these observations and well established radiometric ages for $\mathrm{N}-\mathrm{S}$ and NE-SW mafic dyke swarms, two different assumptions can be drawn; either N-S dyke of this region has different age (older to $\sim 2.37 \mathrm{Ga}$ ) than the established age of 2.21-2.22 Ga or NW-SE mafic dykes of this area are definitely emplaced at $\sim 1.89 \mathrm{Ga}$ (Locations 3 and 5; figure 5). However, observed field data is not supportive to the first assumption. Therefore, this clearly establishes that the D1 mafic dyke must be younger to the $\sim 2.18$ Ga mafic dyke.

Therefore, it is suggested that the Devarakonda area contains spectacular cross-cutting relationships between different generations of Paleoproterozoic mafic dykes. A set of NE-SW D1 mafic dykes can be established as a unit of youngest mafic magmatic event which is emplaced at $\sim 1.89$ Ga. Present work clearly supports the idea of Srivastava et al. (2014a) that all the mafic dykes trending in NE-SW are not emplaced at $\sim 2.37$ Ga but few are emplaced at $\sim 1.89$ Ga. Based on field-setting, it is also seen that NW-SE D4 mafic dyke swarm was emplaced first in the studied region; prior to $\sim 2.21 \mathrm{Ga}$ swarm but perhaps younger to $\sim 2.37 \mathrm{Ga}$ swarm. It is an important observation for two main reasons: (1) A new set of mafic dykes trending in NNW-SSE is identified, which shows oldest mafic magmatic activity in this region, and (2) a possible absence of mafic dykes related to $\sim 2.37 \mathrm{Ga}$ mafic magmatic event. However, more radiometric ages and field data are required to establish a complete picture for the study area in particular and the Eastern Dharwar Craton in general.

\section{Conclusions}

- Based on cross-cutting field relationships, Google Earth Image, and available radiometric ages together with ArcGIS analyses, a detailed Paleoproterozoic mafic dyke map of the Devarakonda region has been presented, which excellently provided distribution of mafic dykes, their trends and relative ages.

- Four sets of Paleoproterozoic mafic dykes, which include (i) $\sim 1.89$ Ga NE-SW mafic dykes, (ii) $\sim 2.18$ Ga WNW-ESE mafic dykes, (iii) $\sim 2.21-2.22$ Ga N-S mafic dykes, and (iv) NNW-SSE mafic dykes have been identified. NNW-SSE mafic dykes have an age older to the $\sim 2.21 \mathrm{Ga}$ and perhaps younger to $\sim 2.37 \mathrm{Ga}$, therefore, identified as a new Paleoproterozoic mafic dyke swarm in the present study. Accordingly, it is established that $\sim 1.89 \mathrm{Ga} \mathrm{NE}-\mathrm{SW}$ mafic dykes are youngest and NNW-SSE trending mafic dykes are the oldest in the studied region.

- Present study also corroborates existence of two mafic dyke swarms having similar trends (NE-SW) but emplaced at two different ages (one is at $\sim 2.37 \mathrm{Ga}$ and other at $\sim 1.89 \mathrm{Ga}$ ), which endorses findings of Srivastava et al. (2014a).

\section{Acknowledgements}

The authors are thankful to the Ministry of Earth Sciences, Government of India, New Delhi, for the financial support through a Research Scheme MoES/16/10/11-RDEAS. Authors are also grateful to Richard Ernst (Department of Earth Sciences, Carleton University, Canada) for suggestions and discussions relevant to this research topic. Authors are thankful to the two anonymous reviewers and the Associate Editor, N V Chalapathi Rao for their constructive comments, which helped much in improving the previous version of the paper. The Head of the Department of Geology, Banaras Hindu University is thanked for extending all necessary facilities during this work.

\section{References}

Almeer M H 2012 Vegetation extraction from free Google Earth Images of deserts using a robust BPNN approach in HSV space; Intern. J. Adv. Res. Comp. Commun. Eng. 1(3) $134-140$.

Bleeker W 2003 The late Archean record: A puzzle in ca. 35 pieces; Lithos 71 99-134.

Bleeker W 2004 Taking the pulse of planet Earth: A proposal for a new multidisciplinary flagship project in Canadian solid Earth Sciences; Geosci. Canada 31 179-190.

Bleeker W and Ernst R E 2006 Short-lived mantle generated magmatic events and their dyke swarms: The key unlocking Earth's paleogeographic record back to $2.6 \mathrm{Ga}$; In: Dyke swarms - time markers of crustal evolution (eds) Hanski E, Mertanen S, Rämö T and Vuollo J (London, Taylor, Francis/Balkema), pp. 3-26.

Bryan S E and Ernst R E 2008 Revised definition of large igneous provinces (LIPs); Earth Sci. Rev. 86 175-202.

Chalapathi Rao N V and Srivastava R K 2012 Kimberlites, lamproites, lamprophyres, their entrained xenoliths, mafic dykes and dyke swarms: Highlights of recent Indian research; Proc. Indian Natl. Sci. Acad. 78 431-444.

Chardon D, Jayananda M, Chetty T R K and Peucat J-J 2008 Precambrian continental strain and shear zone patterns: The south Indian case; J. Geophys. Res. 113 B08402.

Chardon D 2011 Lateral constrictional flow of hot orogenic crust: Insights from the Neoarchaean of South India, geological and geophysical implications for orogenic plateaux; Geochem. Geophys. Geosys. 12 Q02005. 
Coffin M F and Eldholm O 2005 Large igneous provinces; In: Encyclopedia of Geology (eds) Selley R C, Cocks L R M and Plimer I R (Oxford: Elsevier), pp. 315-323.

Ernst R E and Bleeker W 2010 Large igneous provinces (LIPs), giant dyke swarms, and mantle plumes: Significance for breakup events within Canada from 2.5 Ga to the present; Canadian J. Earth Sci. 47 695-739.

Ernst R E and Buchan K L 1997 Giant radiating dyke swarms: Their use in identifying pre-Mesozoic large igneous provinces and mantle plumes; In: Large Igneous Provinces: Continental, Oceanic, and Planetary Volcanism (eds) Mahoney J and Coffin M (Geophys. Mono. Series 100, American Geophys. Union), pp. 297-333.

Ernst R E and Buchan K L 2001 The use of mafic dyke swarms in identifying and locating mantle plumes; In: Mantle plumes: Their identification through time (eds) Ernst R E and Buchan K L, Geol. Soc. Am. Spec. Paper $352247-265$.

Ernst R E and Srivastava R K 2008 India's place in the Proterozoic world: Constraints from the Large Igneous Province (LIP) record; In: Indian Dykes: Geochemistry, Geophysics and Geochronology (eds) Srivastava R K, Sivaji C and Chalapathi Rao V (New Delhi: Narosa Publishing House Pvt. Ltd.), pp. 41-56.

French J E and Heaman L M 2010 Precise U-Pb dating of Paleoproterozoic mafic dyke swarms of the Dharwar craton, India: Implications for the existence of the Neoarchaean supercraton Sclavia; Precamb. Res. 183 416-441.

French J E, Heaman L M, Chacko T and Srivastava R K 2008 1891-1883 Ma southern Bastar-Cuddapah mafic igneous events, India: A newly recognized large igneous province; Precamb. Res. 160 308-322.

Halls H C 1982 The importance and potential of mafic dyke swarms in studies of geodynamic process; Geosci. Canada 9 145-154.

Halls H C, Kumar A, Srinivasan R and Hamilton M A 2007 Paleomagnetism and U-Pb geochronology of eastern trending dykes in the Dharwar craton, India: Feldspar clouding, radiating dyke swarms and the position of india at $2.37 \mathrm{Ga}$; Precamb. Res. 155 47-68.

Hu Q, Wu W, Xia T, Yu Q, Yang P, Li Z and Song Q 2013 Exploring the use of Google Earth Imagery and objectbased methods in land use/cover mapping; Remote Sens. 5 6026-6042.

Huisman O and By Rolf A de 2001 Principles of Geographic Information Systems (The International Institute for Geo-Information Science and Earth Observation), 540 .

Jayananda M, Chardon D, Peucat J-J, Capdevila R and Martin H $20062.61 \mathrm{Ga}$ potassic granites and crustal reworking, Western Dharwar Craton (India): Tectonic, geochronologic and geochemical constraints; Precamb. Res. 150 1-26.

Jayananda M, Peucat J-J, Chardon D, Krishna Rao B and Corfu F 2013a Neoarchean greenstone volcanism, Dharwar Craton, southern India: Constraints from SIMS zircon geochronology and $\mathrm{Nd}$ isotopes; Precamb. Res. 227 $55-76$.

Jayananda M, Tsutsumi Y, Miyazaki Y, Gireesh R V, Kapfo Kowe-U, Tushipokla Hidaka H and Kano T 2013b Geochronologic constraints on Meso and Neoarchean regional metamorphism and magmatism in the Dharwar Craton, southern India; J. Asian Earth Sci. 78 1838.

Kumar A, Hamilton M A and Halls H C 2012a A Paleoproterozoic giant radiating dyke swarm in the Dharwar Craton, southern India; Geochem. Geophys. Geosys. 13 Q02011, doi: 10.1029/ 2011GC003926.
Kumar A, Nagaraju E, Besse J and Bhaskar Rao Y J 2012b New age, geochemical and paleomagnetic data on a $2.21 \mathrm{Ga}$ dyke swarm from south India: Constraints on Paleoproterozoic reconstruction; Precamb. Res. 220-221 123-138.

Legg C A 1994 Remote Sensing and Geographic Information Systems: Geological mapping, mineral exploration and mining (John Willey \& Sons and Praxis Publishing Ltd.), 166p.

Mahadevan T M 2008 Precambrian geological and structural features of the Indian peninsula; J. Geol. Soc. India 72 $35-55$.

Murthy N G K 1987 Mafic dyke swarms of the Indian shield; In: Mafic dyke swarms (eds) Halls H C and Fahrig W F, Geol. Assoc. Canada Spec. Paper 34 393-400.

Murthy N G K 1995 Proterozoic mafic dykes in southern peninsular India: A review; In: Dyke swarms of peninsular India (ed.) Devaraju T C, Geol. Soc. India Memoir 33 81-98.

Murty Y G K, Babu Rao V, Guptasarma D, Rao J M, Rao M N and Bhattacharjee S 1987 Tectonic, petrochemical and geophysical studies of mafic dyke swarms around the Cuddapah basin, south India; In: Mafic dyke swarms (eds) Halls H C and Fahrig W F, Geol. Assoc. Canada Spec. Paper 34 303-316.

Naqvi S M and Rogers J J W 1987 Precambrian Geology of India (Oxford: Oxford University Press), 233p.

Piipsa E J, Smirnov A V, Pesonen L J, Lingadevaru M, Anantha Murthy K S and Deavaraju T C 2011 An integrated study of Proterozoic dykes, Dharwar Craton, southern India; In: Dyke swarms: Keys for geodynamic interpretation (ed.) Srivastava R K (Heidelberg: Springer-Verlag), pp. 33-45.

Radhakrishana T, Krishnendu N R and Balasubramonian G 2007 Mafic magmatism around cuddapah basin: Age constraints, petrological characteristics and geochemical inference for a possible magma chamber on the south western margin of the basin; J. Geol. Soc. India 70 194-206.

Radhakrishna T, Krishnenedu N R and Balasubramonian G 2013 Palaeoproterozoic Indian shield in the global continental assembly: Evidence from the palaeomagnetism of mafic dyke swarms; Earth Sci. Rev. 126 370-389.

Rajesh H M 2004 Application of remote sensing and GIS in mineral resource mapping - An overview; J. Mineral. Petrol. Sci. 99 83-103.

Ramachandra H M, Mishra V P and Deshmukh S S 1995 Mafic dykes in the Bastar Precambrians: Study of the Bhanupratappur-Keshkal mafic dykes swarm; Geol. Surv. India Memoir 33 183-207.

Ramakrishnan M and Vaidyanadhan R 2010 Geology of India (Bangalore: Geol. Soc. India), 994p.

Srivastava R K 2006a Geochemistry and petrogenesis of Neoarchaean high-Mg low-Ti mafic igneous rocks in an intracratonic setting, central Indian craton: Evidence for boninite magmatism; Geochem. J. 40 15-31.

Srivastava R K 2006b Precambrian mafic dyke swarms from the central Indian Bastar Craton: Temporal evolution of the subcontinental mantle; In: Dyke swarms - Time markers of crustal evolution (eds) Hanski E, Mertanen S, Ramo T and Vuollo J (London: Tailor \& Francis Group), pp. $147-159$.

Srivastava R K and Gautam G C 2008 Precambrian mafic dyke swarms from the southern Bastar central India Craton: Present and future perspectives; In: Indian Dyke: Geochemistry, Geophysics and Geochronology (eds) Srivastava R K, Sivaji C and Chalapathi Rao V (New Delhi: Narosa Publishing House Pvt. Ltd.), pp. 367-376.

Srivastava R K and Gautam G C 2009 Precambrian mafic magmatism in the Bastar Craton, central India; J. Geol. Soc. India 73 52-72. 
Srivastava R K, Sivaji Ch and Chalapathi Rao N V 2008 Dyke swarms of Indian shield in space and time; In: Indian Dykes: Geochemistry, Geophysics and Geochronology (eds) Srivastava R K, Sivaji C and Chalapathi Rao V (New Delhi: Narosa Publishing House Pvt. Ltd.), pp. 1-18.

Srivastava R K, Ernst R E, Hamilton M A and Bleeker W 2010 Precambrian large igneous provinces (LIPs) and their dyke swarms: New insights from high-precision geochronology, paleomagnetism and geochemistry; Precamb. Res. (Spec. Issue) 183 379-668.

Srivastava R K, Hamilton M A and Jayananda M 20112.21 Ga large igneous province in the Dharwar Craton, India; Intern. Symp. Large Igneous Provinces of Asia, Mantle Plumes and Metallogeny, Ext. Abst., Irkutsk, pp. 263-266.

Srivastava R K, Jayananda M, Gautam G C, Gireesh V and Samal A K 2014a Geochemistry of an ENE-WSW to NE-SW trending $~ 2.37$ Ga mafic dyke swarm of the Eastern Dharwar Craton, India: Does it represent a single magmatic event? Chemie Erde - Geochemistry $\mathbf{7 4}$ 251-265.

Srivastava R K, Jayananda M, Gautam G C and Samal A K 2014b 2.21-2.22 Ga N-S to NNW-SSE trending Kunigal mafic dyke swarm from Eastern Dharwar Craton, India: Implications for Paleoproterozoic large igneous provinces and supercraton Superia; Mineral. Petrol., doi: 10.1007/s00710-014-0327-5.

Srivastava R K, Samal A K and Gautam G C 2014c Geochemical characteristics and petrogenesis of distinct Paleoproterozoic mafic dyke swarms in space and time and associated large igneous provinces from the Eastern Dharwar Craton, India; Intern. Geol. Rev., doi: 10.1080/00206814.2014.938366.

MS received 30 August 2014; revised 10 February 2015; accepted 24 February 2015 